\title{
Is Grammar Still Important Learning the English Language on Tertiary Level? The Analysis of Students' Attitude
}

\author{
Ramunè Vitalija Ilgūnaitiené ${ }^{1}$ \\ ${ }^{1}$ Vytautas Magnus University, Institute of Foreign Languages, Lithuania \\ Correspondence: Ramunè Vitalija Ilgūnaitienè, Vytautas Magnus University, Institute of Foreign Languages, \\ Gedimino 44-202, Kaunas, Lithuania.
}

Received: March 22, 2021; Accepted: April 19, 2021; Published: April 22, 2021

\begin{abstract}
Lecturers of Vytautas Magnus University Institute of Foreign Languages have noticed that students' English grammar comprehension as well as their interest and motivation for learning it have dropped significantly. It was decided to carry out the research and find the answers to the topical questions. Do students thoroughly understand the importance of grammar in language acquisition context? What are the factors predisposing the diminishing value of grammar? What is the students' insight into the grammar teaching/ learning process in level C1? The questionnaire was compiled and on the basis of a comparative - quantitative method the conclusions were drawn that students do not think that grammar plays an important role in learning the English language, they suppose that their grammar competence is sufficient to be fluent in English, thus, there is no need to continue learning grammar in level C1. If we do not make an attempt to solve this problem, it might lead to a dangerous outcome- the level of the English language proficiency may fall down drastically.
\end{abstract}

Keywords: grammar acquisition, level C1, grammar competence, implicit/ explicit teaching, integrated course

\section{Introduction}

Recently, when the processes of globalization and Euro integration are increasingly setting in the English language has become one of the most important factors enabling young people to find a suitable position in the local and foreign labour markets. It is vital for pursuing education in foreign universities, accessing the latest scientific discoveries, communicating with people on a worldwide scale and, finally, becoming an educated member of the international community. The daily challenges of life fully prove it, and the number of sceptics is vastly decreasingknowing the English language is essential! Thus, English is indispensable for being a global citizen and a fulfilled member of the present-day society. We begin studying it in primary school, continue throughout high school, and while pursuing higher education in colleges and universities. In the process of teaching/learning the English language, we concentrate on several basic competencies that are crucial for acquiring the overall language proficiency. To achieve the best possible result, the language teaching process includes such teaching areas as grammar accuracy, and vocabulary, as well as the development of spoken and written competencies, while using the widest range of methods. For a long time, all parts of the linguistic competence development process were treated equally and were universally recognized as integral parts of the language teaching/learning context. What can we trace these days? Lecturers of Vytautas Magnus University Institute of Foreign Languages in the course of a number of semesters have faced scepticism on behalf of the students. There is a growing perception from the students' point of view that grammar is not important in a modern international context - it is enough to be proficient in spoken language. According to the students, the grammar learnt in school is sufficient for excellent language skills. Moreover, members of the younger generation are exposed to English from an early age - in kindergarten, school, while playing computer games, interacting with peers. They understand it and are well understood by foreigners. Thus, in their opinion, English grammar is not to be learnt at university, the knowledge they have already acquired is sufficient for being a valuable citizen of the world and an equal participant of science and labour markets. The same attitude is reflected in discussions with some high school teachers. The main argument is that it is enough to know the most commonly used grammar areas - this is sufficient to communicate at all levels. Is it true? What is grammar? Why is it important? How much important is it? What factors are responsible for gradual diminishing of its value among students? How do the students view the process of teaching/ learning grammar accuracy on tertiary level? The aim of the article is to find answers to the above presented questions. The research was carried out on the basis of comparative- quantitative method. The questionnaire was compiled and the authors having analysed the data obtained from 268 students of three last semesters have drawn 
certain conclusions which might help to motivate future learners to continue the process of learning grammar in level C1.

\section{Literature Review}

Before analysing the data we have to consider what scholars in the field write about grammar and its importance in the teaching/learning process. What is grammar? The New Oxford American Dictionary defines grammar as "the whole system and structure of a language or of languages in general, usually taken as consisting of syntax and morphology (including inflections) and sometimes also phonology and semantics". But different scholars approach grammar in different ways. A well-known linguist Noam Chomsky presented the idea of universal grammar which declares that "children are born with innate capacity to master language, a power imbued in our species by evolution itself" (Ross). Indian scholars Samuel Praise and K. Meenakshi think grammar to be "merely a set of rules to preserve the written word" (Praise, 2015). Analysing the theories by Chomsky, Praise, and Meenakshi we can draw a conclusion that "grammar has greater implications than simply constructing sentences" (N. Frederick, 2015).

For different members of society grammar has different connotations. "To the ordinary citizen, it connotes to correctness or incorrectness of the language. To a student, it means an analytical and terminological study of sentences" (Debata,2013)." Knowledge of grammar helps the student in the correction of mistakes and improvement of written work. A person cannot learn a foreign language accurately only through the process of unconscious assimilation. Grammar is a sure ground of reference when linguistic habits fail us. So, grammar is indispensable for the student" (Debata 2013). According to Richards and Renandya (2002) grammar aspects are too important to be forgotten in learning English, thus, teachers have to find time to improve students' grammar skills to help develop their language ability. As to Kohli (1984) cited in Debata (2013), "not knowing the grammar of the language is like being a driver who knows nothing about the working of the engine while knowing the grammar is like being a driver who knows not only driving but also the working of the machinery". Grammar has always been a very important part of a language learning process. Why do we have to learn grammar while mastering the English language? Does it really matter? "Grammar is important because it is the language that makes it possible for us to talk about language. As human beings, we can put sentences together even as children - we can all do grammar. But to be able to talk about how sentences are built, about the types of words and word groups that make up sentences - that is knowing about grammar. And knowing about grammar offers a window into the human mind and into our amazingly complex mental capacity" (Haussamen, Brock et al., 2002). We strongly believe that the ideas by the linguists cited firmly prove the importance of grammar.

"No other issue has so preoccupied theorists and practitioners as the grammar debate, and the history of language teaching is essentially the history of the claims and counterclaims for and against the teaching of grammar. Differences in attitude to the role of grammar underpin differences between methods, between teachers, and between learners". (Thornbury, 1999, p.14). Starting with the year 1970 grammar teaching has been the matter for debates. The European Framework of Reference for Languages (CEFR) describes language proficiency on a sixpoint scale from A1 up to $\mathrm{C} 2$. Each level presents the outline of grammar areas a learner has to master. Thus, according to CEFR grammar is a constituent part of a language teaching/ learning process.

Here we come up to the question how grammar has to be taught. According to Newby (2003) there are three general ways of approaching grammar: traditional grammar teaching communicative language teaching and postcommunicative teaching. Paraphrasing Rama and Agullo (2012) traditional grammar teaching comprises the teacher's presentation of a new grammatical item with rules and explanation of form and meaning. Then practical exercises are done which lead to production. Grammatical competence is understood as explicit knowledge of rules. As to communicative language teaching, "with Hymes, Austin and especially Halliday's theories, grammar was considered as both semantic and functional" (Bloor, 2004:2) cited in (Rama and Agullo, 2012). "Thus, grammatical knowledge was performance rather than competence, and was considered as a sub-skill to be learned as procedural knowledge". (Rama and Agullo, 2012). All the above mentioned ways undergo criticism. Paraphrasing Lynch there is no one generally accepted answer to the question which of the methods to choose in the classroom as all the learners are different in terms of age and individual language acquisition capacities.

\section{Data Review}

The research was conveyed in three semesters: 2019 autumn (indicated as $1^{\text {st }}$ semester), 2020 spring (indicated as $2^{\text {nd }}$ semester), and 2020 autumn (indicated as $3^{\text {rd }}$ semester). A total of 268 students participated in the research their answers being the tool for drawing certain conclusions. The participants of the survey were asked to answer a whole range of various questions concerning the learning of English grammar. The questions were composed to answer the main goals of this research - is grammar becoming less important in teaching/learning process of the 
English language, what are the factors predisposing this tendency, how do the students see the process of teaching/learning grammar on tertiary level? The study was based on a comparative-quantitative method.

\section{DO YOU THINK GRAMMAR IS IMPORTANT TO LEARN IN LEVEL C1?}

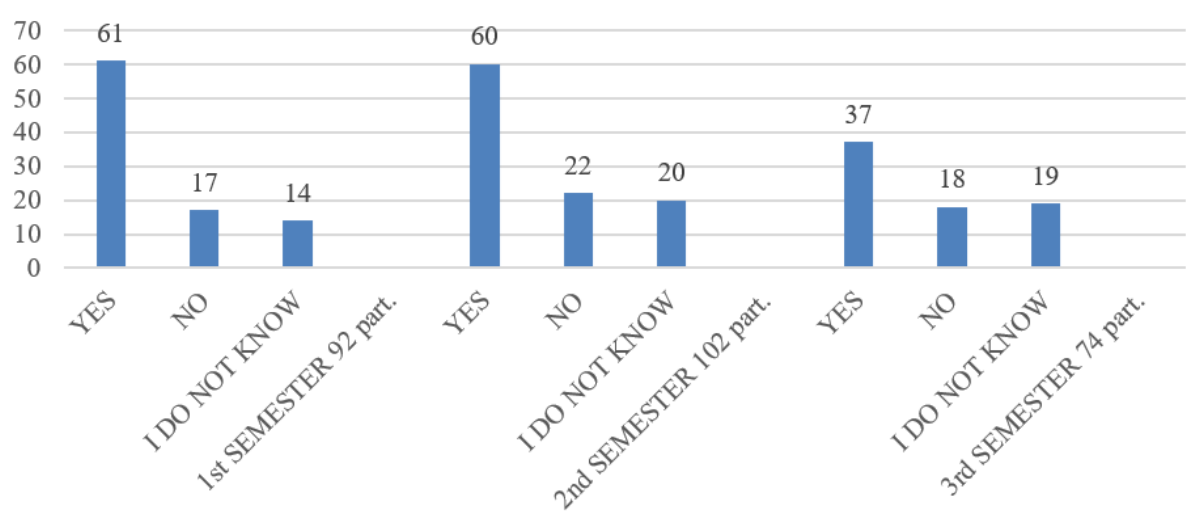

Graph 1. Do you think grammar is important to learn in level C1?

Graph 1 shows that in the $1^{\text {st }}$ semester $66,0 \%$ of the respondents thought grammar to be important while learning the English language, 18,5\% gave a negative answer and 15,2\% were not certain which answer to choose. In the $2^{\text {nd }}$ semester $59,0 \%$ marked grammar as an important factor in the language learning process, $22,0 \%$ answered in a negative way and $19,0 \%$ were hesitant. As to the results from the $3^{\text {rd }}$ semester $-49,5 \%$ gave a positive answer, $24,0 \%$ did not think grammar to be important, $26,6 \%$ were uncertain. The graph indicates a downward tendency in students' attitude towards grammar. The difference between the positive answers from the first and the third semesters is viewed as statistically significant.

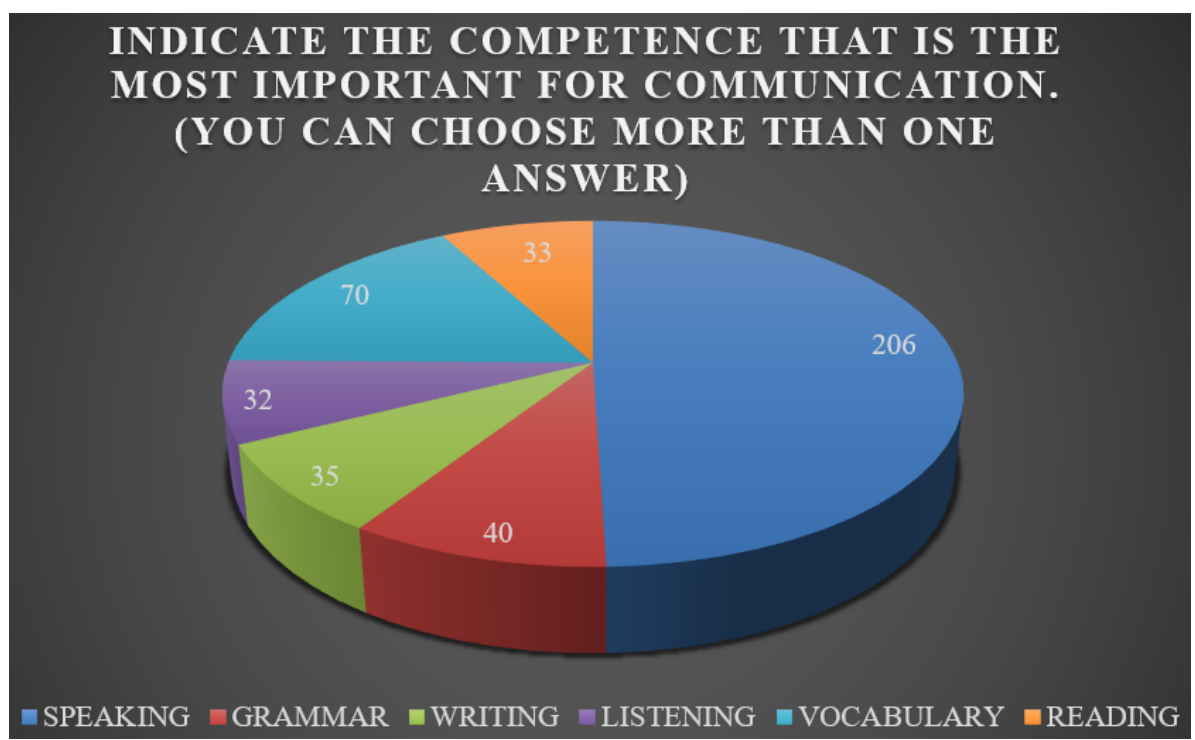

Chart 2. Indicate the competence that is the most important for communication (you can choose more than one competence)

Having analysed the data of the $2 \mathrm{nd}$ chart we see that $77,0 \%$ of the students selected speaking as the most important competence for communication, $26,1 \%$ considered vocabulary to play an important role, $15,0 \%$ chose grammar, $13,0 \%$ thought writing to play the leading role, and $12,3 \%$ gave their cote for reading. The data show that the respondents suppose grammar not to be an important factor assessing language proficiency. The vast majority of students believe speaking to be the most important integral part in the English language learning process. 
Vocabulary takes the second position while grammar occupies only the third place. The chart shows that students do not consider writing and reading to be important parts of the language acquisition process.

\section{INDICATE THE COMPETENCE (-ES) THAT YOU THINK YOU SHOULD \\ IMPROVE. (YOU CAN CHOOSE MORE THAN ONE ANSWER)}

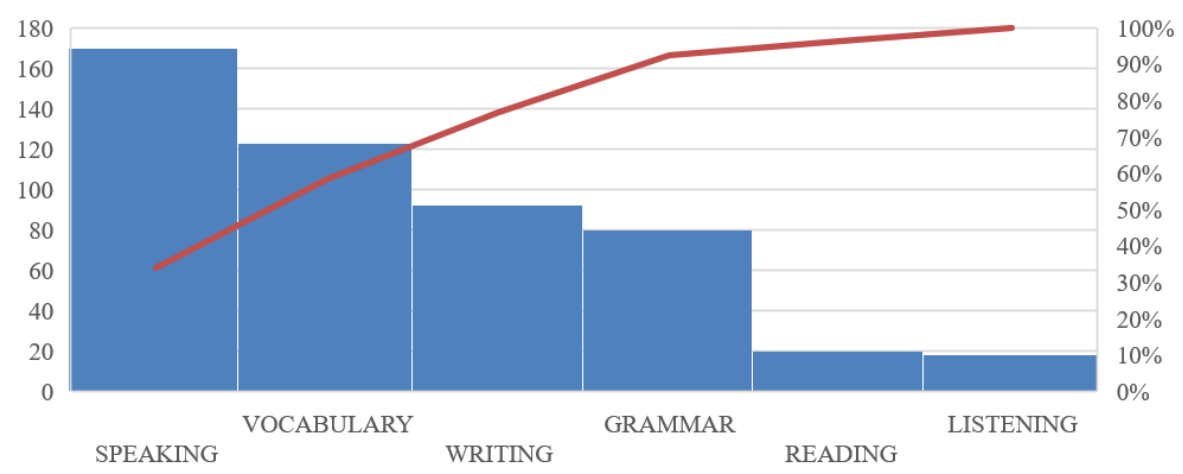

Graph 3. Indicate the competence (-es) that you think you should improve (you can choose more than one competence)

Being asked to indicate the competence they think they have to improve $63,4 \%$ selected speaking, $45,9 \%$ vocabulary, $34,3 \%$ - writing, while $29,8 \%$ thought they needed to improve their grammatical knowledge, $7,5 \%$ were for reading, $6,9 \%$ chose listening. The conclusion can be drawn that students are mostly interested in improving their speaking competence, vocabulary and writing knowledge placing grammar in the fourth position. The least important competencies were selected to be reading and listening.

INDICATE THE MOST IMPORTANT GRAMMAR AREA. (YOU CAN CHOOSE MORE THAN ONE AREA)

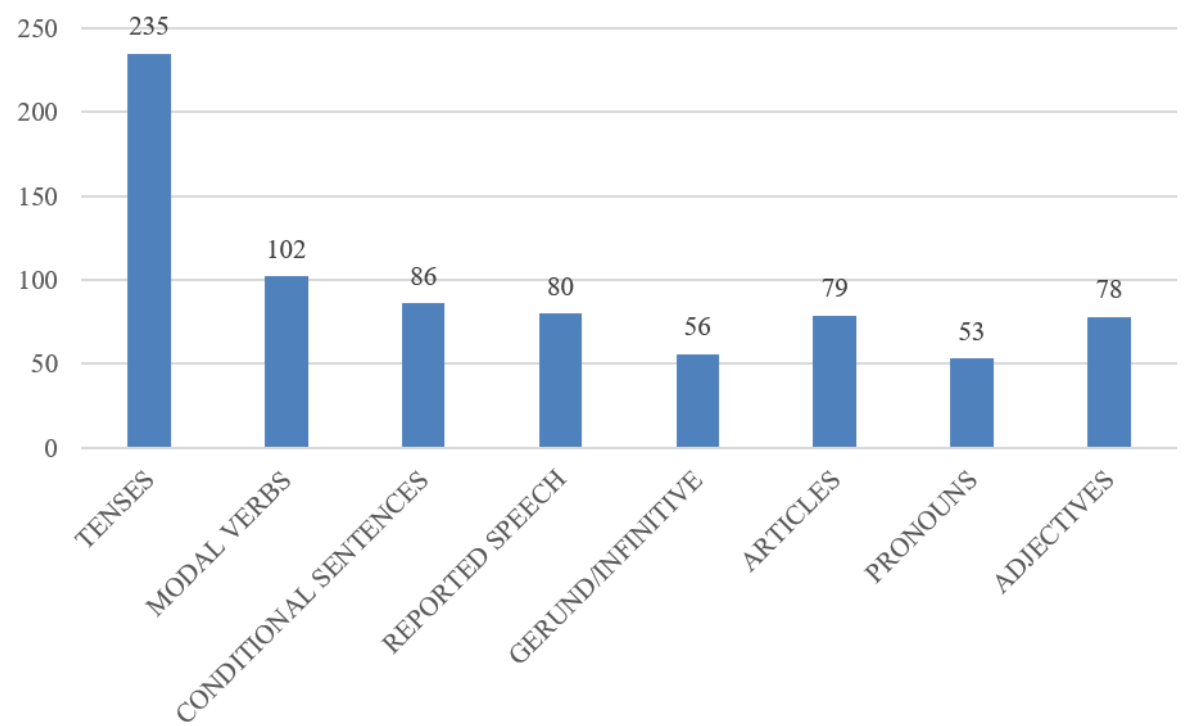

Graph 4. Indicate the most important grammar area (you can choose more than one area)

Graph 4 clearly indicates tenses to be the most important grammar area the vast majority of students would like to improve as they consider it to be necessary to speak the language fluently. $87,7 \%$ chose tenses, $38,0 \%$ were for modal verbs, $32,0 \%$ selected conditional sentences, $29,8 \%$ were for the reported speech, $29,4 \%$ thought articles 
were necessary to improve, $29,1 \%$ were concerned about adjectives $20,8 \%$ chose gerund/infinitive, $19,7 \%$ were for pronouns. In this respect the respondents made their choice having critically assessed their knowledge of the English grammar.

Question 5

Do you think you have gained enough knowledge of the English language grammar when you finished high school and passed English state exam? The majority of the respondents suppose that they gained enough knowledge of the English language grammar at high school- $60,0 \%$, though the average of 30,0\% admit that their knowledge is still not sufficient. Students believe that in the course of high school they covered English language levels A1, A2, B1, B2 acquiring full content of grammar.

\section{WHAT OTHER COMPETENCES SHOULD BE INCORPORATED IN GRAMMAR TEACHING COURSE: (YOU CAN CHOOSE MORE THAN ONE ANSWER)}

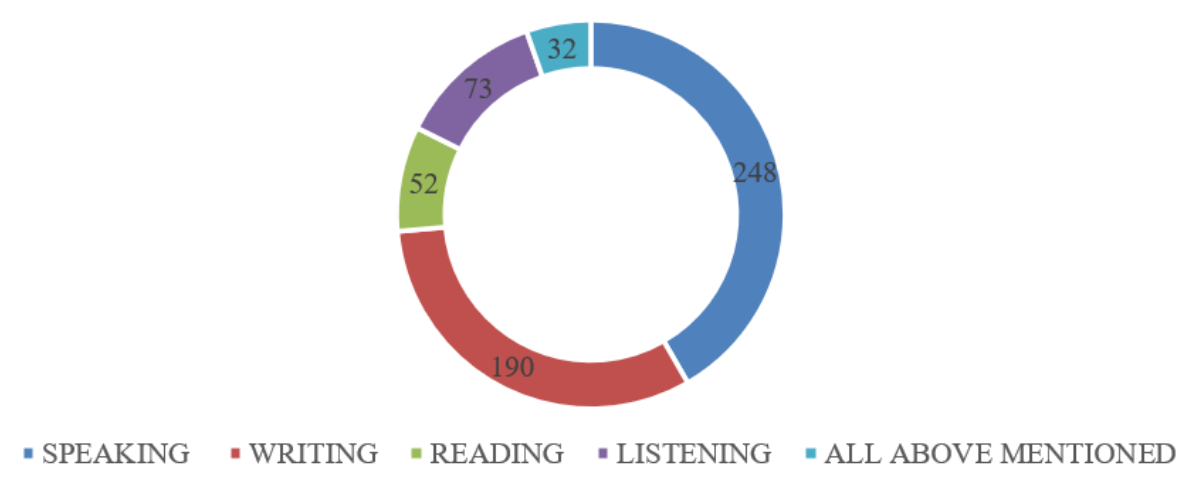

Chart 6 . What other competences should be incorporated in grammar teaching course?

The chart reveals that $92,5 \%$ of the respondents think that grammar teaching should be combined with speaking, $70,9 \%$ give priority to writing, 27,2\% choose listening, 19,4\% would like reading to go alongside with grammar, $11,9 \%$ think that all of the above mentioned competences have to be integrated into grammar teaching process.

\section{WHAT ARE THE MAIN FACTORS DIMINISHING STUDENTS' INTEREST IN LEARNING GRAMMAR (YOU CAN CHOOSE MORE THAN ONE ANSWER)}

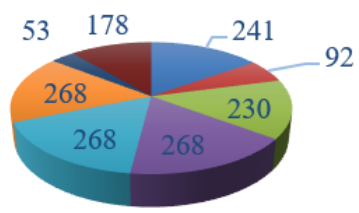

$$
\begin{aligned}
& \text { - GAINED ENOUGH KNOWLEDGE AT HIGH SCHOOL } \\
& \text { - PASSED THE STATE EXAMINATION WITH HIGH SCORE } \\
& \text {-LEARNED GRAMMAR IN LEVELS A1-B2 AT UNIVERSITY } \\
& \text {-HAVE CONSTANT EXPOSURE TO ENGLISH } \\
& \text {-UNDERSTAND NATIVE SPEAKERS/FOREIGNERS } \\
& \text { - NATIVE SPEAKERS / FOREIGNERS UNDERSTAND THEM } \\
& \text { - LIVED IN FOREIGN COUNTRIES } \\
& \text { - GRAMMAR IS NOT THE MOST IMPORTANT COMPETENCE }
\end{aligned}
$$

Chart 7. What are the main factors diminishing students ${ }^{`}$ interest in learning grammar? 
The chart shows that $100 \%$ of the respondents have constant exposure to the English language, $100 \%$ understand native speakers /foreigners, $100 \%$ are understood by native speakers /foreigners, $89,9 \%$ gained enough knowledge at high school, 85,8\% learned grammar in levels A1-B2 at university, $66,4 \%$ think that grammar is not the most important competence, $34,3 \%$ passed the state examination with high score, $19,8 \%$ lived in a foreign country.-all these factors, according to the respondents, prove that they are proficient in English, thus their grammar accuracy is sufficient.

\section{SHOULD GRAMMAR BE TAUGHT EXPLICITLY OR IMPLICITLY OR BOTH. WHY?}

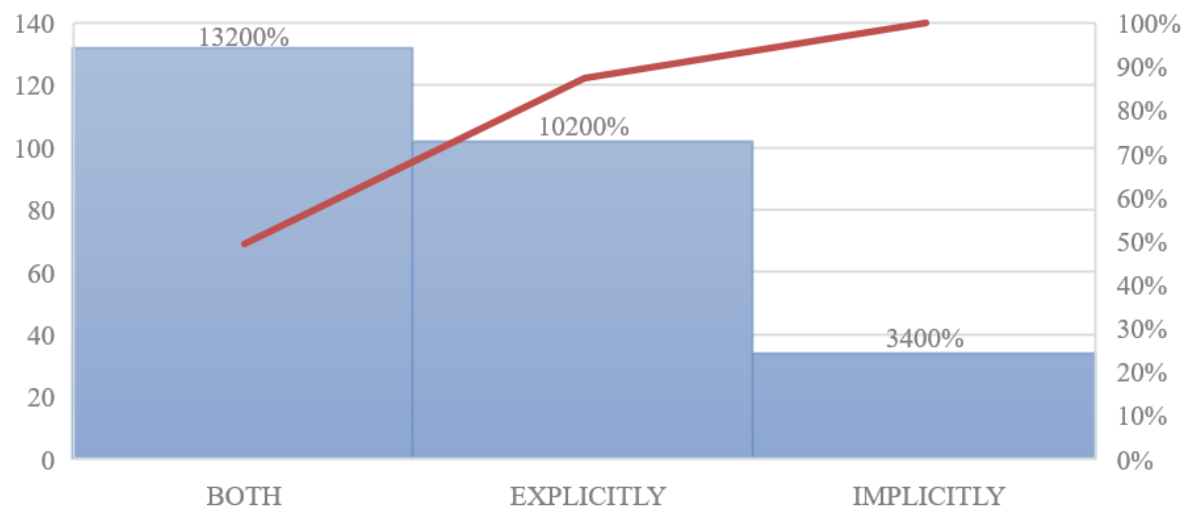

Graph 8. Should grammar be taught explicitly, implicitly or both? Why?

Graph 8 shows that $38,0 \%$ of the respondents think that grammar has to be taught explicitly, $12,6 \%$ choose implicit teaching as priority, $49,3 \%$ are for the combination of both- explicit and implicit teaching of grammar, as only the combination of two methods can guarantee the most efficient process.

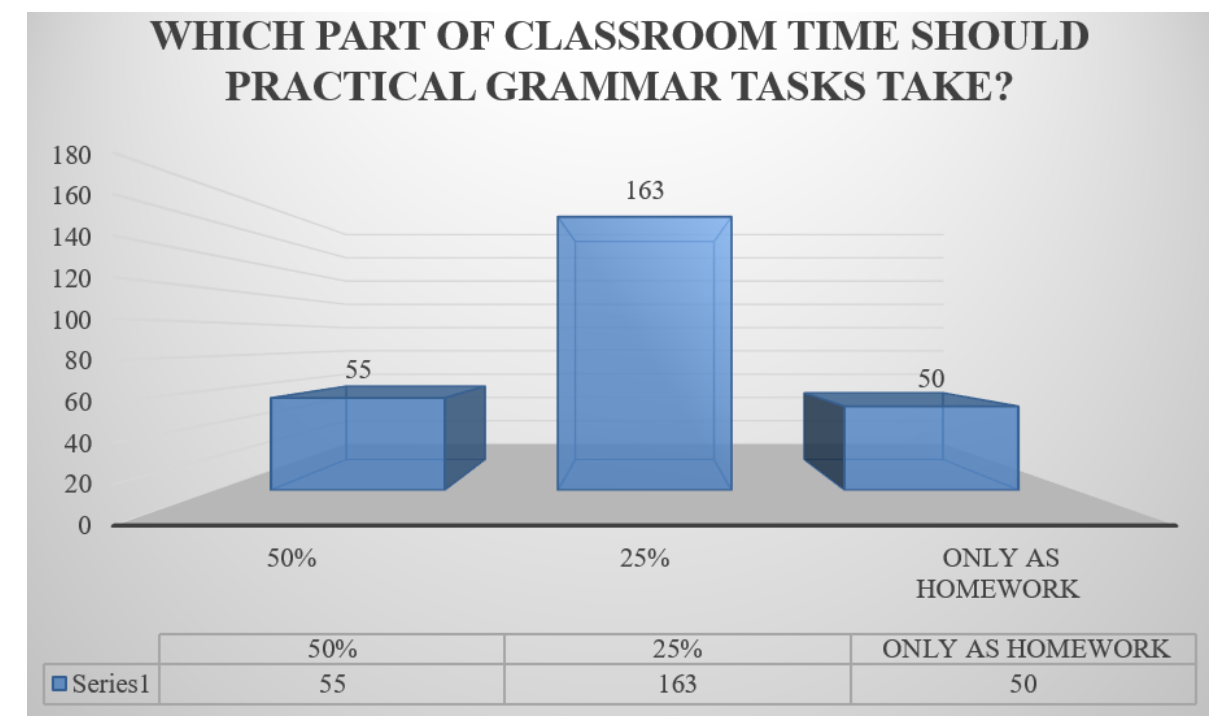

Graph 9. Which part of the classroom time should practical grammar tasks take?

According to graph 9- $60,8 \%$ of students would like practical grammar tasks to take $25 \%$ of classroom time, $20,5 \%$ are for $50 \%$ of classroom time to be given to grammar practice, $18,6 \%$ think that practical tasks have to be given only as homework, as they suppose it would be the most efficient way to organise practical learning of grammar. 


\section{WHAT COMMUNICATIVE TASKS SHOULD BE INCORPORATED IN A LECTURE (YOU CAN CHOOSE MORE THAN ONE ANSWER)}

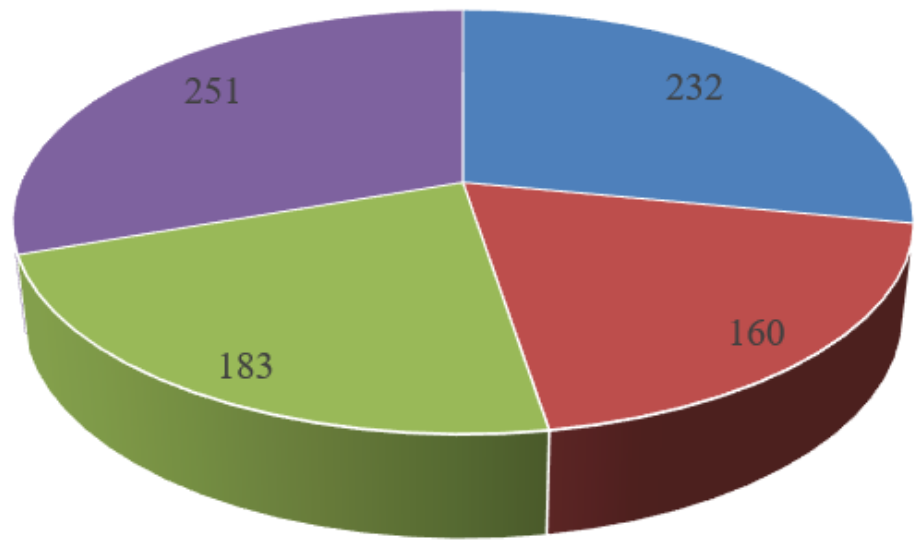

- 1. DISCUSSION ON VARIOUS TOPICS

- 2. GROUP PROJECTS

" 3. INDIVIDUAL PRESENTATIONS

Chart 10. What communicative tasks should be incorporated in a lecture?

According to chart $10.93,65 \%$ give preference to interactive tasks, $87,5 \%$ are for discussions on various topics, $68,2 \%$ prefer individual presentations, $59,7 \%$ choose group projects. That would do the course more effective and interesting.

\section{WHAT PARTS SHOULD FINAL EXAMINATION COMPRISE (YOU CAN CHOOSE MORE THAN ONE ANSWER)}

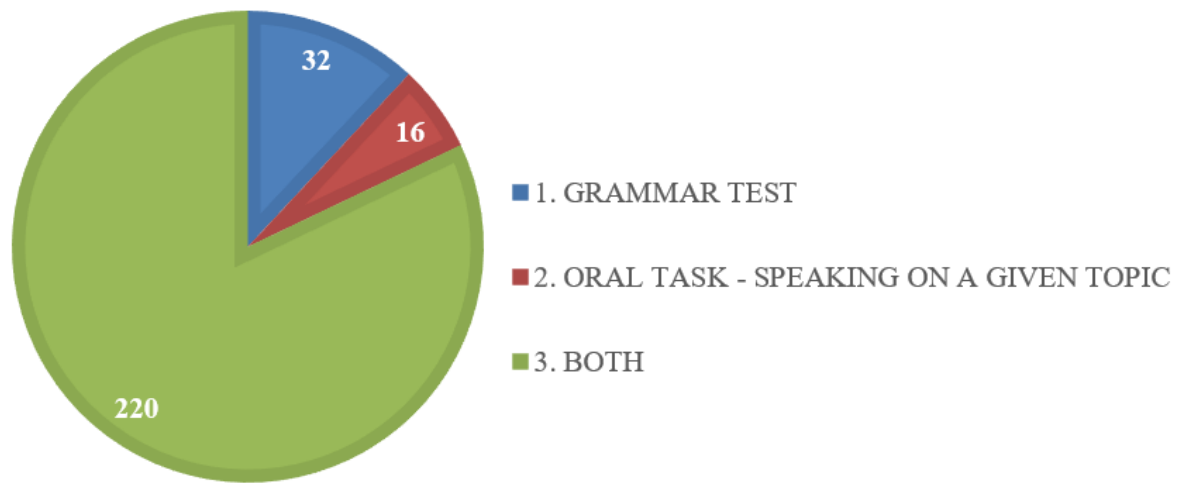

Chart 11. What parts should final examination comprise?

Chart 11 indicates that $11,9 \%$ of the respondents would prefer grammar test, 5,95 choose an oral task, $82,0 \%$ give preference to both the above mentioned combined as their final examination as comprising two parts would provide a full assessment of the course.

\section{Discussion}

268 students of Vytautas Magnus University participated in the survey containing 11 grammar teaching/ learning oriented questions. Having analysed the data obtained from the research we can see that the majority of the respondents give preference to speaking as the most important competence in language proficiency. However, 
about $30 \%$ state that grammar is but necessary to master and admit that they still need to improve their knowledge in the field. Alongside with this, it is evident, that the number of students interested in learning grammar in level $\mathrm{C} 1$ is reducing (comparing the data of three semesters) statistically significantly. According to the literature reviewed, the position of grammar in language teaching/learning process has been gradually gaining strength in recent years, though the results of this particular study reveal a cardinally different outcome. As to grammar content which is supposed to be the most important for grammar accuracy, they suppose the tenses of the English language and the verb system on the whole take the first place. The biggest part of VMU students in the research think that grammar has to be taught incorporating speaking into the course, which fully corresponds to the opinion of authors cited. The vast majority of the respondents believe that grammar is not the most important factor responsible for language proficiency as they have daily exposure to the English language, they communicate with the native speakers and other foreigners on the basis of English and understand them as well as are understood by them properly, they gained enough grammar knowledge at high school and their state examination score proves it, they learned grammar in levels A1- B2 at university which firmly guarantees that their English grammar knowledge is extended as the requirements for the above mentioned levels correspond to CEFR guidelines. All of the previously mentioned reasons prove that they have mastered the English language, thus their grammar accuracy is sufficient. As to explicit and implicit ways of teaching grammar the bigger number of participants would like both methods to be combined as they complement each other and pave the way to the most efficient teaching/ learning process. The students think that they have to be explained grammar rules giving structured and direct instruction while implicit way of teaching prepares them for communicative situations when grammar rules very often lose their value and are forgotten. Bigger percentage of the respondents expressed the opinion that grammar practice has to take $1 / 4$ of the classroom time while the rest of the time should be given to speaking practice: interactive tasks, discussions, group projects, individual presentations on topical issues. The vast majority of the respondents think that the final examination has to be the combination of two parts- grammar test and speaking task.

\section{Conclusions}

To improve the teaching of grammar on tertiary level and to make the course attractive for students and focusing on their needs the lecturers of VMU conducted a survey the main goal of which was to state whether university students clearly see the role of grammar in the process of learning the English language as the lecturers have noticed that the students' interest in learning grammar faces scepticism. Having analysed the data the lecturers can draw a conclusion that bigger part of the respondents do not think that grammar is vitaly important in language learning process, the majority still think their knowledge of grammar to be sufficient as they learned it at high school and/or at university, they have constant exposure to the English language, communicate with the native speakers and understand them properly as well as are understood by them. The students in the research give preference to the integrated course of grammar and speaking competences, in which grammar has to be taught both explicitly and implicitly. The authoress of the article firmly believe that combining students' attitude and lecturers' experience and practice we can achieve the highest results. The study aims at specifying the most important problem in the English language learning context - the reducing role of grammar and factors diminishing its value. If the teachers of English overlook this problem the outcomes might lead to significant deterioration of the English language quality among the representatives of young intelligent generation. The article might be beneficial for high school teachers and university lecturers. The further research should go deeper into the problem analysed in the study.

\section{References}

Adams, Susan (2015). Why Grammar Counts at Work. Forbes Magazine, 20 July 2012. Web. 13 Jan.2015. Retrieved from http://www.forbes.com/sites/susanadams/2012/07/20/why- grammar- counts -...

Adger, Carolyn Temple, Catherine E. Snow, \& Donna Christian (eds) (2002). What Teachers Need to Know about Language. Washington DC. Center for Applied Linguistics.

Bloor, T. (2004). The Functional Analysis of English: a Hallidayan Approach. London; New York: Arnold. https://doi.org/10.4324/9780203774854

Council of Europe. (2001). Common European Framework of Reference for Languages: Learning,Teaching, Assessment. Cambridge:Cambridge University Press. www.coe.int/lang-CEFR.

De Beaugrande Robert. (1984). Forward to the Basics: Getting Down to Grammar. College Composition and Communication, 35. https://doi.org/10.2307/357464

Debata, P. K. (2013). The Importance of Grammar in English Language Teaching- a Reassessment. 13(5). Retrieved from http://www.languageinindia.com 
Frederick, Nicole (2015). The Professional Importance of Grammar and How It Should Be Taught. PIT Journal: Cycle, 6.

Gorney, E. (2012). The Language of Texting Altering English or a Language of Its own. Undergraduate Review: A Journal of Undergraduate Student Research, 13. http://fisherpub.sjfc.edu/ur/vol13/iss1/9

Haussamen, B., et al. (2002). Some Questions and Answers About Grammar. https://doi.org/10.1002/bl.38620026302

Leech, G. N. (1994). Students Grammar-Teachers Grammar- Learners Grammar. In M. Bygate et al. (eds). Grammar and the Language Teacher. New York: Prentice Hall.

Lehman, C. (2007). Linguistic Competence: Theory and Empire. Folia Linguistica, 41(3/4). https://doi.org/10.1515/flin.41.3-4.223

Newby, D. (2006). Teaching grammar and the question of knowledge. In A. B. Fennerand and D. Newby (eds.) Coherence of Principles, Cohesion of Competences: Exploring Theories and Designing Materials for Teacher Education. Graz/Strasbourg: European Centre for Modern Languages/Council of Europe Press, 1-11.

Praise, S., \& Meenakshi, K. (2015). Importance of Grammar in Communication. International Journal of Research, Studies in Language Learning, 41(2015). Consortia Academia. Jan. 2015. Web.14 Jan.2015. Retrieved from $\mathrm{http}: / /$ www.consortiacademia.org/index.php/ijrsll/article/view/789/365

Rama, J., Luque, L., \& Agullo, G. (2012). The Role of the Grammar Teaching: From Communicative Approaches to the Common European Framework of References for Languages. Revista de Linguisticay Lenguas Aplicadas, 7(1). https://doi.org/10.4995/riyla.2012.1134

Richards, J., Renandya, C., \& Willy, A. (2002). Methodology in Language Teaching an Anthology of Current Practice. Cambridge University Press. https://doi.org/10.1017/CBO9780511667190

Rod, Ellis. (2006). Current Issues in the Teaching of Grammar:An SLA Perspective. TESOL Quarterly, 40(1), 83107. https://doi.org/10.2307/40264512

Saaristo P. (2015). Grammar is the Heart of Language: grammar and its role in language learning among Finnish university students. In J. Jalkanen, E. Jokinen, P. Taalas (eds), Voices of Pedagogical Development- expanding, enhancing and exploring higher education language learning. Dublin. https://doi.org/10.14705/rpnet.2015.000296

Thornbury, S. (1999). How to Teach Grammar. Harlow: Longman.

\section{Copyrights}

Copyright for this article is retained by the author(s), with first publication rights granted to the journal.

This is an open-access article distributed under the terms and conditions of the Creative Commons Attribution license (http://creativecommons.org/licenses/by/4.0/). 